\title{
接合部パネルが塑性化する鉄骨構造骨組の \\ 地震応答性状に関する振動台実験 \\ SHAKING TABLE TEST ON EARTHQUAKE RESPONSE BEHAVIOR \\ OF STEEL MOMENT RESISTING FRAMES \\ WITH YIELDING JOINT PANEL
}

\author{
長谷川 隆* \\ Takashi HASEGAWA
}

\begin{abstract}
This paper describes the results of shaking table test on earthquake response behavior of steel moment resisting frames with yielding joint panel. The main objective of the shaking table test is to investigate the effect of energy absorption at joint panel zone on inelastic response behavior and total energy absorption capacity of the frames. The result of the shaking table test is summarized as follow. In the case where the relative member strength of panel to beam $\left(R_{p}\right)$ of the specimen is about 0.65 , it was found that the energy absorption at the joint panel zone became dominant in the specimen and this had an effect on increasing the total energy absorption capacity of the specimen.
\end{abstract}

Keywords : shaking table test, joint panel, earthquake response behavior, beäm fracture, relative member strength of panel 振動台実験、接合部パネル、地震応答性状、梁破断、パネル耐力比

1. はじめに

1995年兵庫県南部地震におろけ中低層鉄骨構造建物の典型的な被 害形態の 1 つして、梁端部の脆性的な破断が挙げられる1)。この ような被害を受けた鉄骨構造建物の中には、梁端部の破断ととも に、接合部パネル（以下、パネルと呼ぶ）も降伏している建物2）が あった。この建物において、梁端部が破断した柱梁接合部の被害状 況を観察すると、柱梁接合部の破壊形態は、パネルの塑性化の有無 によって、以下の $2 つ に$ 場合分けできる。

(A) 梁端部だけが破断し、パネルは無被害の場合。

（B）梁端部の破断とともに、パネルも降伏している場合。

梁端部の破断とともに、パネルも降伏するかどうかは、梁に対す るパネルの相対的な耐力比が強く影響する。実際に建設されている 中低層鉄骨構造建物で、柱に冷間成形角形鋼管を使用した場合で も、パネルが柱や梁に比べて相対的に弱くなる場合が多いことが指 摘されている3)。この被災建物の柱梁接合部の (B) の破壊形態も、 パネルが柱や梁よりも相対的に弱く、パネルが早期に降伏したこと によって発生したものであると考えられる。

パネルが塑性化する場合に、骨組全体の地震応答に及ほす影響を 解析的に検討した研究は、既にいくつか行われている。それらの結 果からは、パネルの塑性化は、骨組の特定層への損傷集中を緩和す る効果がある4〉６ことや、パネルを建物の主要なエネルギー吸収
部材として活用できる可能性22、7)、8) が示されている。

一方、実験的研究として、パネルが柱や梁部材に先行して降伏す る場合に、骨組全体の変形能力に及ほす影響を明らかにした実験が 行われ、パネルが先行降伏してエネルギー吸収することによって、 骨組全体の塑性変形能力が向上することが示されている9)、10)。ま た、パネルによって主体的にエネルギー吸収し、パネルの座屈に よって耐力低下が生じるパネル崩壊型骨組を実験的に検討したもの もある11)。さらに、パネルの耐力、剛性及び荷重-変形関係を明ら かにするための実験 12)、13) も行われている。

これらの実験的研究は、パネルが柱、梁に先行して降伏し、パネ ルによって主体的に地震エネルギーを吸収することを想定したもの であり、実験結果は、パネルを建物の主要なエネルギー吸収部材と する耐震設計法が有用であることを示唆するものであろう。しか し、これらの既往の実験研究は、静的な載荷実験によるものであ り、地震動による動的な荷重下でも、同様の効果が得られるかどう か、現状では必ずしも明らかではない。

そこで本論文では、パネルが梁及び柱に先行して塑性化する鉄骨 構造骨組に関して、地震動による動的荷重下での弾塑性応答性状を 明らかにするために行った振動台実験にういて述べる。特にこの実 験では、上述した（A）、（B）2つの破壊形態となる骨組の地震応 答性状を比較するために、梁とパネルの耐力比を実験パラメーター

* 建設省建築研究所第三研究部 研究員 ·博士 (工学) Research Engineer, Structural Engineering Department, Building Research Institute, Ministry of Construction, Dr. Eng. 
とした4体の骨組試験体を使って、パネルのエネルギー吸収の割合 によって、骨組全体のエネルギー吸収能力や、梁及びパネルの弾 塑性挙動がどのように変化するか明らかにする。

\section{2. 振動台実験の方法}

\section{1 試験体及び加振装置}

振動台実験では、角形鋼管柱と $\mathrm{H}$ 形鋼梁よりなる 4 体の骨組試 験体について、地震動を入力した加振を行ない、パネルのエネル ギー吸収の違いによるそれぞれの試験体の弾塑性応答性状への影 響を比較する。試験体の概要と柱梁接合部スカラップ近傍の詳細 を図 1 に示す。試験体は、冷間成形角形鋼管柱と溶接組立 $\mathrm{H}$ 形鋼 梁を通しダイヤフラム形式で溶接接合したL形の形状の骨組であ る。このL形の試験体2つを直交梁及びブレースにより結合させて 立体骨組としたものを 1 つの試験体とし、この立体骨組の試験体 4 体（No.1〜 No.4）の実験を行なう。

表 1 には、4体の試験体の柱、梁の断面、パネル板厚及び柱/梁 耐力比 $\left(R_{c}\right) 、 ハ ゚ ネ ル$ 耐力比 $\left(R_{p}\right)$ 等を示す。柱/梁耐力比とは、梁 の耐力に対する柱の耐力の比であり、バネル耐力比とは、梁の耐 力と柱の酎力の小さい方に対するパネルの耐力の比である。柱/梁 耐力比 $\left(R_{c}\right)$ 、パネル耐力比 $\left(R_{p}\right)$ の定義を次式に示す。

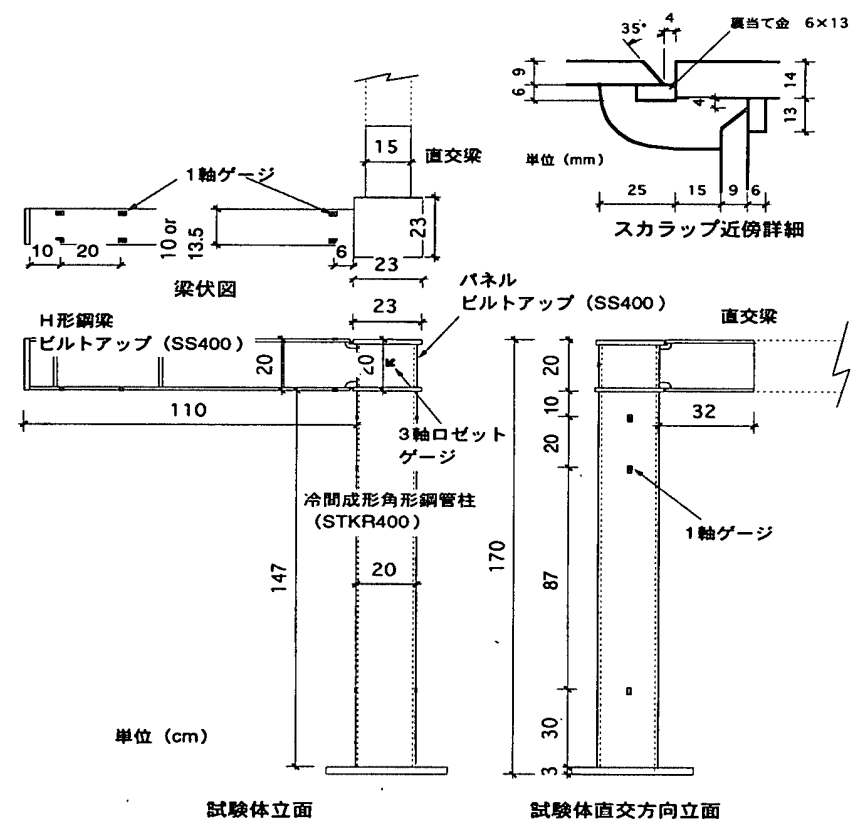

$$
\begin{aligned}
& R_{c}=\frac{C M_{p}}{{ }_{B} M_{p}} \\
& R_{p}=\frac{{ }_{P} M_{p}}{\min \left[{ }_{C} M_{p},{ }_{B} M_{p}\right]}
\end{aligned}
$$

ここで $C M_{p} 、{ }_{B} M_{p}$ は、それぞれ柱、梁の全塑性モーメントである。 ${ }_{P} M_{p}$ はパネルの降伏耐力であり、次式 ${ }^{13)}$ で定義する值とした。

$$
{ }_{P} M_{P}=\frac{16 \sigma_{y}}{9 \sqrt{3}} D_{B} D_{C} t
$$

ここで $\sigma_{y}$ はパネルの降伏応力度、 $D_{B}$ は梁フランジ中心間距離、 $D_{C}$ は 柱フランジ中心間距離、 $t$ はパネル板厚である。柱、梁、パネルの うちどの部材が先に塑性化するか正確に知るためには、上記で計 算される柱、梁、パネルの耐力を節点位置に変換した節点塑性モー メント 14) を比較する必要がある。節点塑性モーメントによって計 算した $R_{c}$ 及び $R_{p}$ の值を、参考值として表中の（）内に記載した。

柱は 4 体の試験体すべてが同一断面であり、板厚は $9 \mathrm{~mm}$ で外形 寸法は $20 \mathrm{~cm}$ の冷間成形角形鋼管 (STKR400) である。梁は溶接組 立材（SS400）で、No.1、No.2 試験体のフランジ幅が $10 \mathrm{~cm}$ である のに対して、No.3、No.4 試験体は $13.5 \mathrm{~cm}$ である。また、パネルも 車当て金を用いて、4枚の板 (SS400)の溶接組立により製作し、そ の板厚はNo.1、No.3が9mmで、No.2、No.4は $5 \mathrm{~mm}$ である。この 実験では梁とパネルの耐力比を、設計で意図した值にするため、試 験体の梁フランジとパネルは、同一の鋼材 (9mm の板厚の SS400 材）を使って溶接組立で製作している。また、パネルの板厚が $5 \mathrm{~mm}$

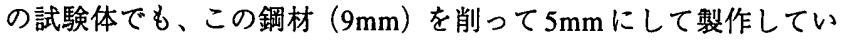
る。このようして、 $R_{p}$ が $0.66 、 0.83 、 1.18 、 1.5$ となる 4 体の試験体 を設定した。なお、表 1 で示す $R_{c} 、 R_{p}$ の值は、表 2 で示す試験体各 部位の素材試験結果に基づいて計算したものである。

試験体に慣性力を作用させるための重りの重量 $\left(W_{t}\right)$ は、梁の

\begin{tabular}{|c|c|c|c|}
\hline 試験体の部位 & 鋼種 & $\begin{array}{c}\text { 降伏応力度 } \\
\left(\mathrm{t} / \mathrm{cm}^{2}\right)\end{array}$ & $\begin{array}{c}\text { 引張強度 } \\
\left(\mathrm{t} / \mathrm{cm}^{2}\right)\end{array}$ \\
\hline $\begin{array}{l}\text { 梁フランジ }(9 \mathrm{~mm}) \text { 及 } \\
\text { びバネル }(9 \mathrm{~mm}, 5 \mathrm{~mm})\end{array}$ & SS400 & 3.03 & 4.65 \\
\hline 梁ウェフ $(6 \mathrm{~mm})$ & SS400 & 3.07 & 4.60 \\
\hline 角形鋼管柱 $(9 \mathrm{~mm})$ & STKR400 & 4.04 & 4.87 \\
\hline タイヤフラム（14mm) & SS400 & 2.86 & 4.46 \\
\hline
\end{tabular}
耐力により計算されるベースシャー係数 $\alpha_{1}$ が扰よそ 0.65 前後とな

表 2 素材試験結果一覧

\begin{tabular}{|c|c|c|c|c|c|c|c|c|}
\hline $\begin{array}{l}\text { 試験 } \\
\text { 体名 }\end{array}$ & 柱断面 & 梁断面 & $\begin{array}{c}\text { パネル } \\
\text { 板厚 }\end{array}$ & $\begin{array}{l}\text { 柱/梁耐力 } \\
\text { 比 }(R c)\end{array}$ & $\begin{array}{l}\text { パネル耐 } \\
\text { 力比 }(R p)\end{array}$ & $\begin{array}{c}\text { 重り重量 } \\
\left(W_{t}\right)\end{array}$ & $\begin{array}{c}\text { ベースシ } \\
\text { ヤー係数 } \\
\left(\alpha_{1}\right)\end{array}$ & $\begin{array}{c}\text { ベースシャ } \\
\text { 一係数 }\left(\alpha_{\min }\right)\end{array}$ \\
\hline No.1 & $\square-200 \times 9$ & BH $-200 \times 100 \times 6 \times 9$ & $9 \mathrm{~mm}$ & $\begin{array}{c}2.80 \\
(2.64) \\
\end{array}$ & $\begin{array}{c}1.50 \\
(1.52) \\
\end{array}$ & 12.59ton & 0.63 & 0.63 (梁) \\
\hline No.2 & $\square-200 \times 9$ & BH $-200 \times 100 \times 6 \times 9$ & $5 \mathrm{~mm}$ & $\begin{array}{r}2.80 \\
(2.67) \\
\end{array}$ & $\begin{array}{c}0.83 \\
(0.89) \\
\end{array}$ & 12.59ton & 0.63 & 0.52 (パネル) \\
\hline No.3 & $\square-200 \times 9$ & BH-200× $135 \times 6 \times 9$ & $9 \mathrm{~mm}$ & $\begin{array}{r}2.21 \\
(2.10) \\
\end{array}$ & $\begin{array}{r}1.18 \\
(1.23) \\
\end{array}$ & 14.85ton & 0.68 & 0.68 (梁) \\
\hline No.4 & $\square-200 \times 9$ & $\mathrm{BH}-200 \times 135 \times 6 \times 9$ & $5 \mathrm{~mm}$ & $\begin{array}{r}2.21 \\
(2.13) \\
\end{array}$ & $\begin{array}{c}0.66 \\
(0.71)\end{array}$ & 14.85ton & 0.68 & 0.45 (パネル) \\
\hline
\end{tabular}

図 1 試験体の概要

表 1 試験体断面等一覧

柱/梁耐力比、パネル耐力比の欄の（）内の数字は、各部材の節点塑性モーメントによって計算した値。

$\alpha_{1}$ は梁の耐力で計算したベースシャー係数、 $\alpha_{\text {min }}$ 最も耐力の小さい部材で計算したベースシャー係数であり（）内 にその部材を示す。 


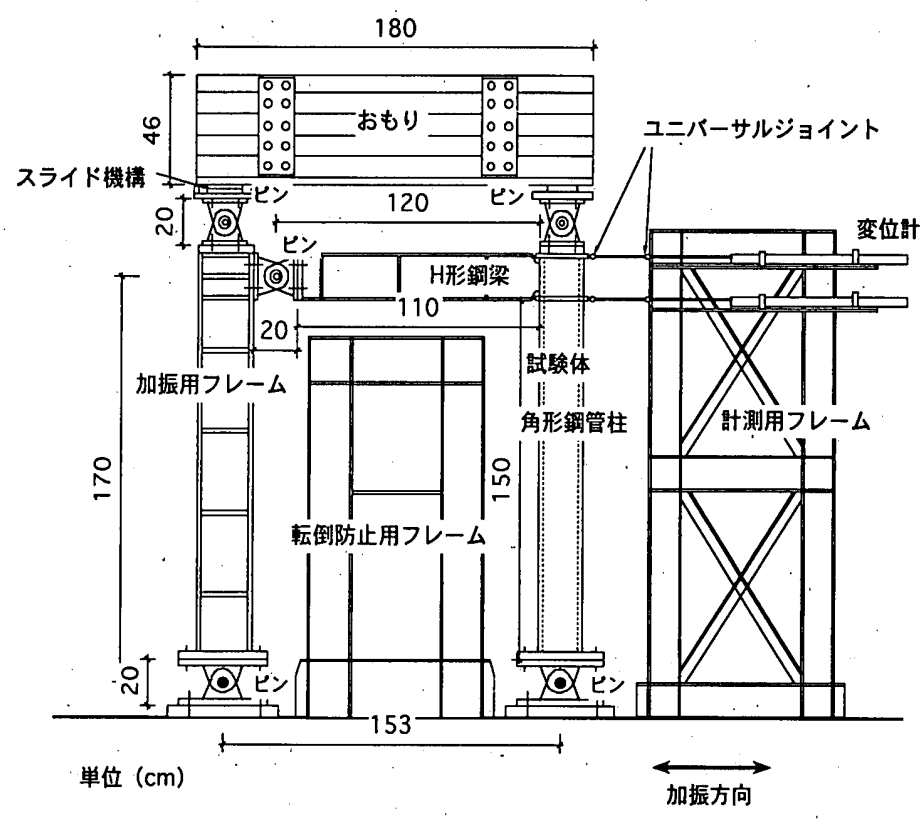

図 2 載荷装置の概要

るように設定している。この值は、試験体の設計のために行なっ た地震応答解析の結果に基づいて決定している。No.1、No.2 試験 体は、重りが 12.59tonで、 $\alpha_{1}$ が0.63であるのに対して、No.3、No.4 は、重りが 14.85 tonで、 $\alpha_{1}$ が 0.68 である。No.3、No.4についても、 No.1、No.2 と同一の值の $\alpha_{1}$ としたかったが、No.3、No.4では試験 体を含めた振動台上のすべての重量が20ton以上となり、振動台の 載荷重量の制限を越え、振動台の制御ができなくなる可能性が生 じたため、No.3、No.4の $\alpha_{1}$ は、No.1、No.2よりやや大きい設定と なっている。なお、表中には最も耐力の小さい部材で計算したべー スシヤー係数 $\alpha_{\text {min }}$ も示している。パネル耐力比 $\left(R_{p}\right)$ が1 以下であ るNo.2、No.4試験体は、パネルが先行降伏するため、 $\alpha_{\min }$ の值が小 さくなっている。

図1の柱梁接合部スカラップ近傍の接合詳細に示すように、試験 体の柱梁接合部は通しダイヤフラム形式である。通しダイヤフラ 么の板厚は $14 \mathrm{~mm}$ で、柱面からの出は $15 \mathrm{~mm}$ である。この試験体 のスカラップ形状は、塑性変形能力を向上させるために、特別に スカラップ形状を工夫したもの ${ }^{14)}$ ではなく、従来から一般的に用 いられている形状のものである。

加振用フレーム、計測用フレーム、転倒防止用フレーム及び重 り等を含めた振動台実験全体の概要を図 2 に示す。加振用フレーム と試験体の柱は、振動台にピン接続し、加振用フレームと試験体 梁もピン接続されている。それらの上部には試験体に慣性力を作 用させるための重りをピン接続して乗せている。加振中に梁が曲 げ変形すると考えられるが、その曲げ変形による軸方向の伸びち ぢみを拘束しないように、重りと加振用フレームの接続のピンは、 同時にスライイドするようにしている。

\section{2 計測方法}

この実験における主な計測項目は、振動台上の加速度、試験体 の応答加速度、試験体の変形、試験体の柱、梁のせん断力、パネル の歪み等である。試験体の応答加速度は、試験体の直交梁のフラ ンジ面上に加速度計をセットして計測する。変位計による試験体
の変形の計測は、図2で示すように試験体の柱梁接合部の上下の通 しタイヤフラム位置の応答変形を、2つの構面の柱梁接合部につい て、合計 4個所行なう。図 1 で示すように、試験体の柱、梁、パネ ルに添付した歪みゲージからは、それぞれの部材の塑性化の状況 や、部材の応答せん断力を知ることができる。すなわち、柱、梁の 部材端及びパネルに添付した歪みゲージからは部材の塑性化の状 況を計測する。一方、柱、梁部材において弾性状態を維持すると 考えられる2断面に添付した歪みゲージからは、2つの断面位置で の曲げモーメントを求め、その断面間のモーメン.ト勾配から、部 材の応答せん断力を算出する。これらの測定值の収録のサンプリ ング周波数は $200 \mathrm{~Hz}$ である。

\section{3 加振方法}

振動台による加振は水平 1 方向であり、入力地震動は 1995 年兵 庫県南部地震において神戸海洋気象台で観測された地震動の南北 成分 (以下 JMA Kobe と呼ぶ) の最大加速度 $818 \mathrm{gal}$ を約 600gal (最 大速度は約 $65 \mathrm{kine}$ ）に低減したものを使用した。最大加速度を $600 \mathrm{gal}$ に低減したのは、振動台の加振振幅の限界 $( \pm 150 \mathrm{~mm}) に$ よる制限のためである。この入力地震動による弾塑性加振によっ て試験体が倒壊しない場合には、同様の加振を繰り返し行ない、試 験体が倒壊するまで実験を行なう。試験体の倒壊とは、試験体が 自立できずに、転倒防止用のフレームにもたれかかる状態になる ことをいう。なお、各試験体ともこの弾塑性加振の前に、ランダ ム波による共振試験及びJMA Kobeの最大加速度を $30 \mathrm{gal}$ 程度にし た弾性加振実験を行ない、各試験体の弾性固有周期や減衰を調べ る。

\section{3. 振動台実験の結果}

\section{1 弾性固有周期及び減衰}

表 3 は共振試験の結果から得られた、4体の試験体の弾性固有周 期及び減衰を示す。 4 体の試験体の固有周期は、 $0.345 \mathrm{sec}$ から $0.366 \mathrm{sec}$ の範囲にある。パネル板厚を $9 \mathrm{~mm}$ から $5 \mathrm{~mm}$ にすることに よって、No.1 と No.2 試験体は $0.015 \mathrm{sec}$ 周期が伸び、No.3 と No.4 では $0.004 \mathrm{sec}$ 伸びている。これらの試験体の固有周期の違いは小 さく、この固有周期の違いが原因となって、それぞれの試験体へ の地震動の入力エネルギーが大きく変化することはないと考えら れる。減衰は共振曲線から算定しているためか、ややばらつきが 大きく、 $0.36 \% \sim 0.97 \%$ の範囲となっている。平均では $0.73 \%$ あ る。

表 3 固有周期と減衰

\begin{tabular}{|c|c|c|}
\hline 試験体名 & $\begin{array}{c}\text { 固有周期 } \\
(T)\end{array}$ & 減衰 $(h)$ \\
\hline No.1 & $0.345 \mathrm{sec}$ & $0.86 \%$ \\
\hline No.2 & $0.360 \mathrm{sec}$ & $0.72 \%$ \\
\hline No.3 & $0.362 \mathrm{sec}$ & $0.36 \%$ \\
\hline No.4 & $0.366 \mathrm{sec}$ & $0.97 \%$ \\
\hline
\end{tabular}

\section{2 試験体への総エネルギー入力}

図3はNo.1〜No.4の各試験体の実験において、振動台上で計測 された入力地震動（JMA Kobe）のエネルギースペクトル 15) $\left(V_{E}\right)$ 
である。○は試験体への総エネルギー入力 $(E)$ の速度換算值 ${ }^{(5)}$ で

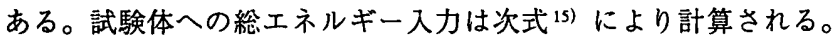

$$
E=-\int_{0}^{t_{0}} \dot{y} M \ddot{z_{0}} d t
$$

żはは振動台上で計測される入力地震動の加速度、yは試験体の相対 変位、 $t_{0}$ は入力地震動の全継続時間、 $M$ は重りの質量。

図中のカッコ内は加振回数を示す。例えば、No.1 試験体は 2 回 目の弾塑性加振により試験体が倒壊したことを表し、(1 回目)の 表示は、1回目の加振による入力地震動のエネルギースペクトルと 試験体への総エネルギー入力（E）の速度換算値（Oの記号）であ る。(1 回目 +2 回目) の表示は、1 回目と 2 回目の和を意味してい るが、これは加振毎の総エネルギー入力の和を速度換算したもの である。

No.1、No.2試験体では2回目の加振により試験体が倒壊し、No.3 は 3 回目、No.4は 4 回目の加振により、試験体が倒壊したことを 示している。なお、4体の試験体はすべて最終的には梁端部が破断 して倒壊に至っている。これらの破断は、梁フランジの絞りを伴 うものであり、いずれも延性的な破断であった。これらの図から は、入力地震動のエネルギースペクトルと試験体への総エネル ギー入力の速度換算值（○の記号）の関係は、試験体が塑性化す ることによる固有周期の伸びを考慮して、固有周期を $0.05 \sim 0.1$ 秒 程度長めに見積もることによって、加振を何回か繰り返しても、よ く対応していることがわかる。

梁断面が同一で、パネル板厚だけが異なるNo.1 試験体（ $R_{p}$ は

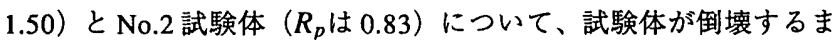
で (1 回目 +2 回目)の総エネルギー入力の速度換算值 (○の記号) を比較すると、No.1 は $231 \mathrm{~cm} / \mathrm{s} 、 N o .2$ は $230 \mathrm{~cm} / \mathrm{s}$ であり、その值 は、ほとんど変わらない。同様に、パネル板厚だけが異なるNo.3 ( $R_{p}$ は 1.18) と No.4 ( $R_{p}$ は0.66) について比較すると、No.3は $259 \mathrm{~cm} /$ $\mathrm{s}$ で、No.4は $305 \mathrm{~cm} / \mathrm{s}$ あった。すなわち、骨組が倒壊するまでに吸
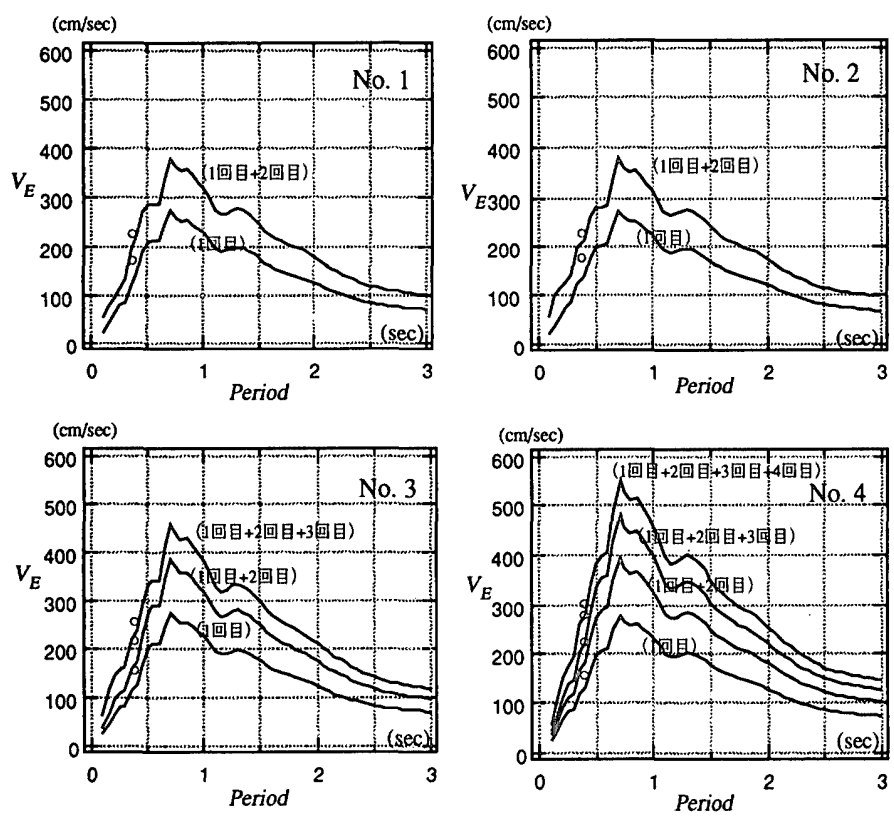

図 3 入力地震動の $V_{E}$ スペクトルと試験体の総エネルギー入力
収する総エネルギー入力は、骨組の $R_{p}$ が 0.8 程度の場合は、 $R_{p}$ が 1 以上の場合とほとんど変わらないが、 $R_{p}$ が 0.65 程度になると、 $R_{p}$ が 1 以上の場合と比べ、その值が大きくなると考えられる。これは、 パネルによる大きなエネルギー吸収が影響していると考えられる。 このようなパネルのエネルギー吸収が及はす効果をさらに詳しく 調べるため、次に試験体の各部位の弾塑性応答に着目して比較す る。

\section{3 各試倹体の弾塑性応答性状}

実験を終了した段階で、すべての実験において、各試験体には ねじれ振動を生じていないことが確認されたため、以下の応答值 の表示では、試験体の片側の構面のみの応答値を示す。

\section{（1）骨組全体の弾塑性応答}

図 4 は、弾塑性加振の結果得られた各試験体（No.1～No.4）の 倒壊するまでの層せん断力係数 $(Q / W)$ と層間変形角 $(R)$ の関係 を示す。実線が 1 回目、細い実線が 2 回目、点線が 3 回目、細い点 線は4回目の加振を示す。ここで、層せん断力係数は、片側構面の 骨組の層せん断力 $(Q)$ をその構面の負担重量（W）で除した値と する。骨組の層せん断力（Q）は、柱に添付した歪みゲージの値に よって計算した柱のせん断力からP- $\Delta$ 効果による骨組の耐力低下 分を減じた值である。

No.1 と No. 2 試験体を比較すると、パネルの板厚を薄くしている No.2の方が、最大耐力がわずかに小さいが、変位応答はほとんど
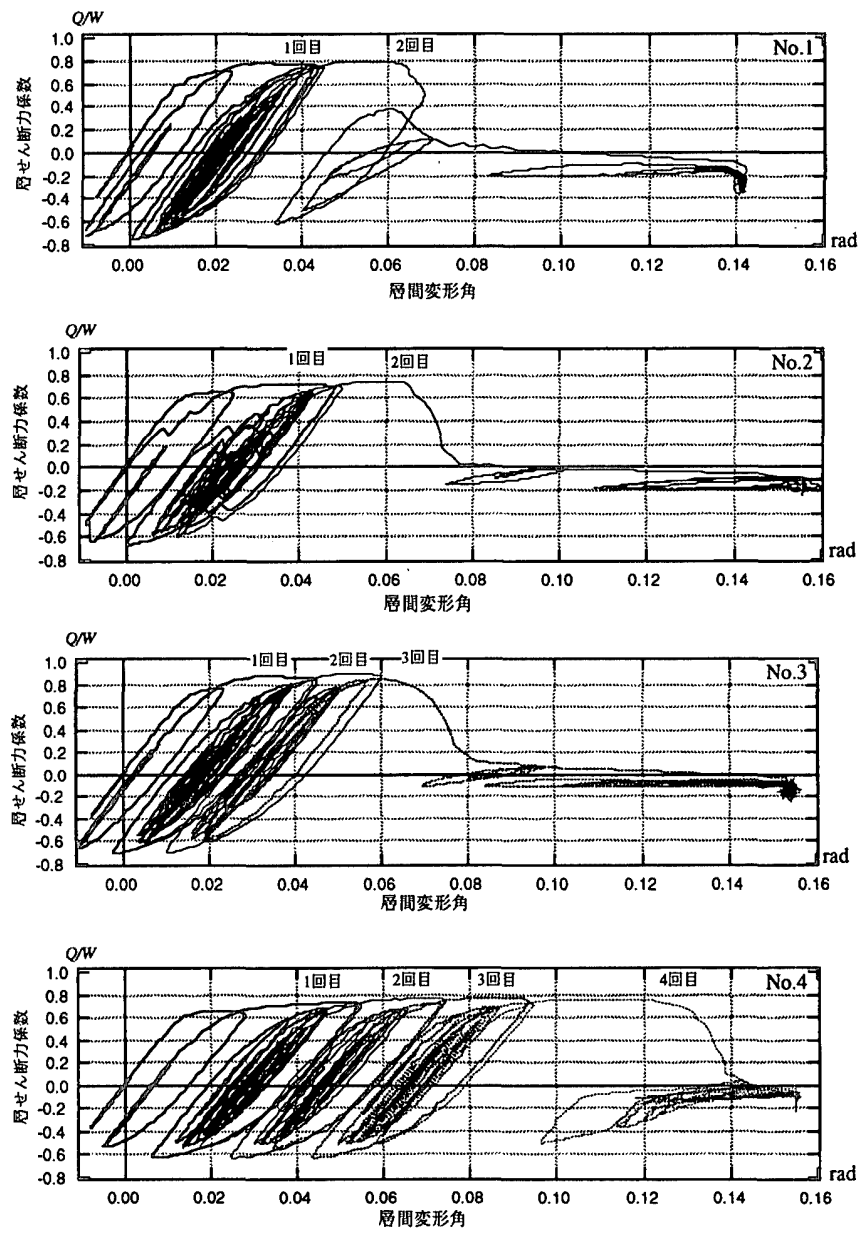

図 4 層せん断力係数と層間変形角の関係 
差がないことがわかる。目視による柱梁接合部の最終的な破壊状 況からは、No.2ではパネルがわずかにせん断変形しているのが確 認できたが、梁端部の破断状況はほとんど変わらなかった。

No.3とNo.4試験体の結果を比較すると、パネル板厚を薄くした No.4の方が、降伏耐力及び最大耐力ともに、No.3より小さいこと がわかる(約 $10 \%$ 低下している)。降伏耐力が小さいのは、No.4で は、パネルが梁より先に降伏したためである。これらの試験体は ともに、最終的には、同一断面である梁が破断することによって 倒壊しているが、パネルの耐力が小さいNo.4の方が、骨組全体の 最大耐力が小さくなっている。

一方、骨組全体の塑性変形能力については、逆にパネルの耐力 が小さいNo.4 試験体の方が、大きくなっている。No.3では 3 回目 の加振で倒壊したのに対して、No.4は3 回目では倒壊せず、4回目 の加振で倒壊している。また、骨組の酎力が低下するまでの最大 層間変形角は、No.3では 0.06rad程度であるが、No.4はその2倍の $0.12 \mathrm{rad}$ まで変形が延びている。ただし、1 回毎の加振による復元 力特性を比較すると、パネルの板厚が薄く、降伏耐力が小さいNo.4 の方が変形がやや大きくなっている。最終的な破壊状況としては、 No.4では、パネルが大きくせん断変形（座屈）しているのが確認 された。

\section{（2）梁端部の弾塑性応答}

図 5 にはNo.3とNo.4試験体の梁端フェイスモーメントと梁端回 転角の関係を示す。この梁端部フェイスモーメントは、柱に作用 するせん断力を梁端部フェイス位置に変換した值である。2つの図 の比較からは、パネルを弱くした場合に、その影響で梁端部の復 元力特性がどのように変化するか知ることができる。

材料試験結果から得られる梁の全塑性モーメントの計算值は 863t-cmである。降伏モーメントに関してはNo.3とNo.4試験体に、 大きな差は見られないが、最大モーメントに関しては、パネルが
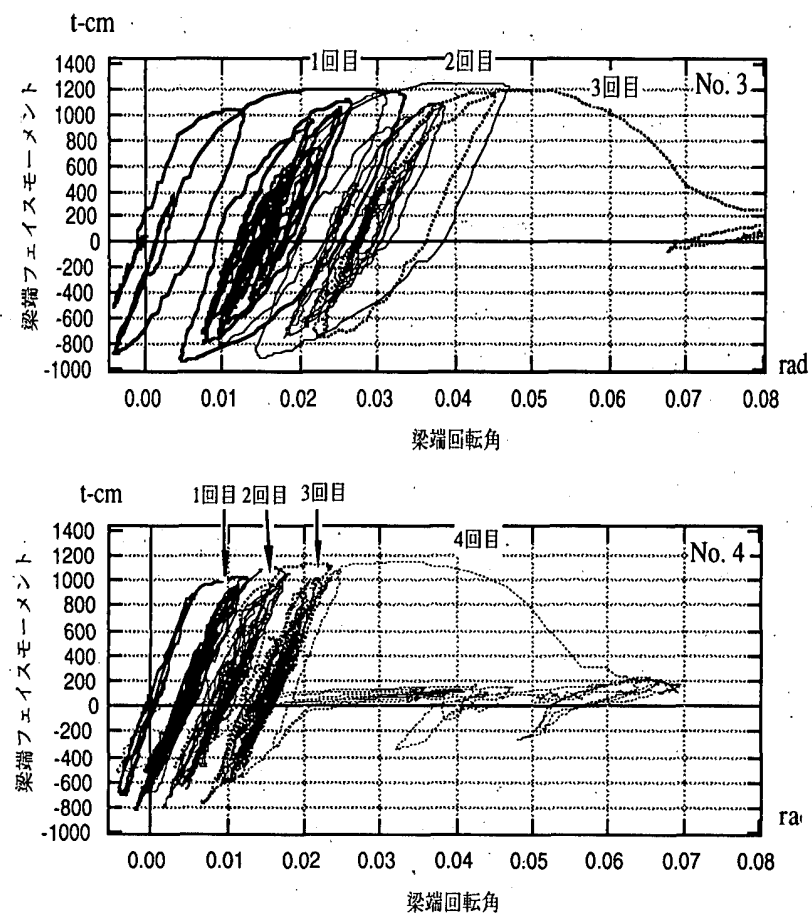

図 5 梁端モーメント - 回転角関係
弱いNo.4はNo.3より7\%程度小さい值である。また、塑性変形能 力に関しても、No.3 試験体が $0.06 \mathrm{rad}$ 程度で耐力低下しているのに 対して、No.4 試験体は 0.04radで耐力低下している。すなわち、パ ネルが塑性化する骨組の梁は、パネルが塑性化しない骨組の梁に 比べて、同一断面であっても、その耐力と塑性変形能力が低下す ることがわかる。

一方、1回の加振による梁の変形量は、パネルの耐力が小さい No.4試験体の変形は、明らかにNo.3より小さい。これは、No.4は、 パネルによる地震エネルギー吸収が支配的だからである。ただし、 No.4でも、1 回目の加振加ら梁端部には $0.01 \mathrm{rad}$ 程度の変形は生じ ている。

\section{（3）パネルの弾塑性応答}

図6はNo.1〜No.4各試験体のパネルモーメントとパネルせん断 歪み $(\gamma)$ の関係を示す。パネルモーメントは、梁端部フェイス モーメントから柱のせん断力により生じるモーメントを差し引い た值である。パネル耐力比 $\left(R_{p}\right)$ が1 以上であるNo.1 と No.3 は、 最終加振においても、パネルがせん断降伏していないことがわか る。一方、R $R_{p}$ が 1 以下である No.2.とNo.4 は 1 回目の加振でせん断 降伏し、その歪みの值も2\%程度かそれ以上であることがわかる。 図7は、目視による観察で、パネルのせん断変形が最も著しかっ た No.4 試験体のパネルモーメントとパネルせん断変形角. $\left.{ }_{p} \theta\right)$ の
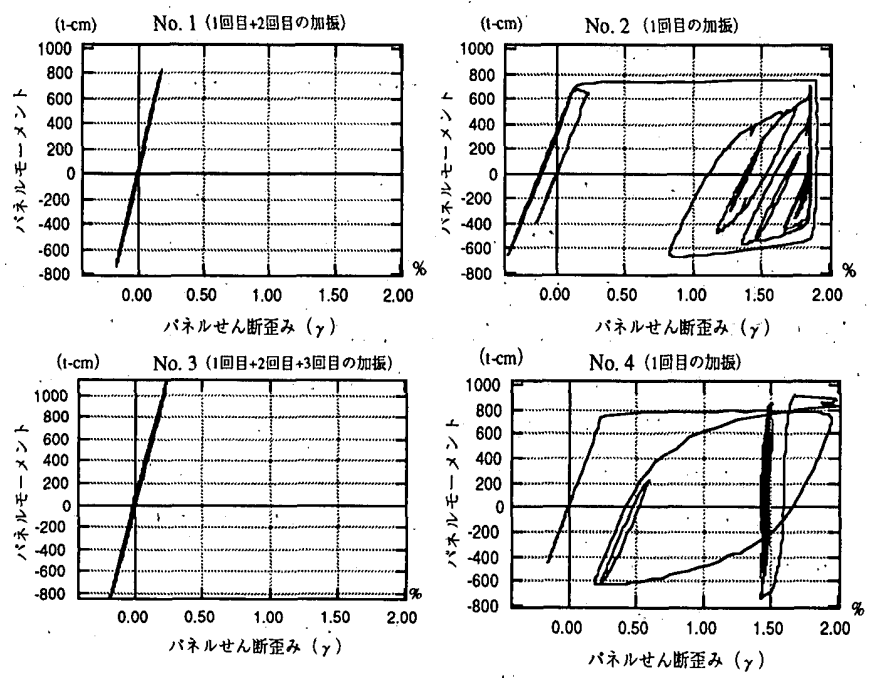

図 6 パネルモーメント -せん断歪み関係

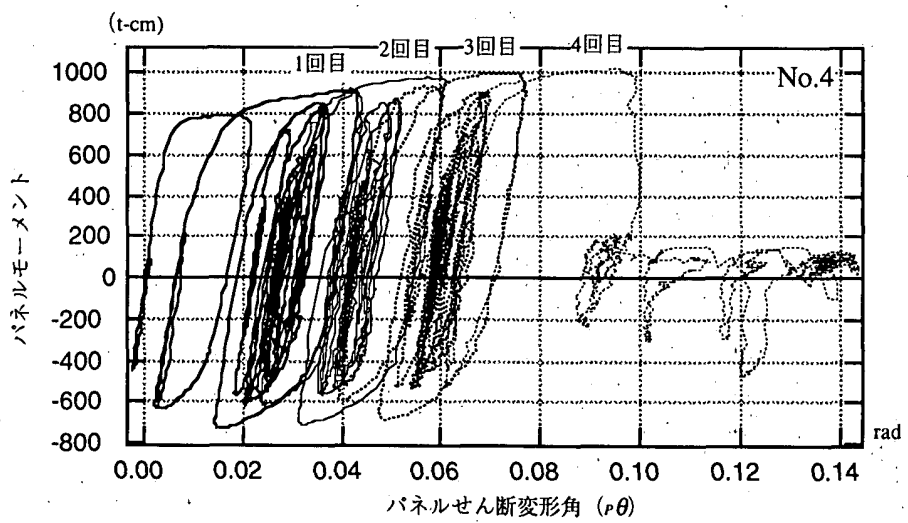

図7 パネルモーメント-せん断変形角関係 
関係を示す。パネルせん断変形角については、この実験ではパネ ルのせん断变形を直接計測できなかったので、層間変形角 $(R)$ か ら、梁端の回転角による層間変形角成分と柱の回転角による層間 変形角成分を差し引いて、パネルの変形による層間变形角成分を 算出し、その值からパネルのせん断变形角 $(p \theta)$ を計算している。

図からは、No.4試験体では 1 回の加振でパネルが約 $0.04 \mathrm{rad}$ 変形 し、最終的には 4 回の加振で $0.1 \mathrm{rad}$ まで変形しているのがわかる。 この試験体では3回目の加振によって、パネルのせん断座届が観察 され、4回目の加振によって、その座屈波形がさらに大きくなった。 最終的には、梁端部が破断して倒壊したため、パネル自体が耐力 低下することなく、どこまで変形できるか明らかではないが、こ の実験においては、パネルは $0.1 \mathrm{rad}$ 程度まで酎力低下なく変形可 能であることが確認できた。

\section{4 パネル耐力比と部材の損傷の関係}

表 4 は、No.3 と No.4 試験体に関して、（4）式で計算した総エネ ルギー入力と、図 5 及び図 7 で示した梁及びパネルのモーメント 回転角関係から得られる履歴吸収エネルギー及び平均累積塑性变 形倍率 $(\bar{\eta})$ を、加振毎に示したものである。平均累積塑性変形倍 率 $(\bar{\eta})$ は次式で定義される。

$$
\bar{\eta}=\frac{1}{2} \cdot \frac{W}{M_{p} \theta_{p}}
$$

ここで、Wは梁またはバネルの履歴吸収エネルギー、 $M_{p}$ は梁の全塑 性モーメントまたは（3）式で示すパネルの降伏耐力、的は梁また はパネルの弾性限回転角。

No.3 と N .4 試験体の加振毎の総エネルギー入力を比較すると、 No.4の方が、No3よりやや大きい。これは、この固有周期付近で の入力地震動のスペクトルが右上がりであり（図3参照）、No.4は パネルの早期の塑性化によって、No.3よりも相対的に固有周期が 長くなるために、入力エネルギーが増大したものと考えられる。試 験体が倒壊するまでの試験体への総エネルギー入力の合計の值は、 No.3 は 254t-cm、No.4は 353t-cm であり、パネルの板厚を薄くし たNo.4の方が、No.3よりも約 1.4 倍のエネルギー吸収能力がある ことがわかる。

No.4 試験体では、梁とパネルの履歴吸収エネルギーの和が、総 エネルギー入力より大きくなり、エネルギーの収支バランスがつ

表 4 総エネルギー入力と梁及びパネルの損傷

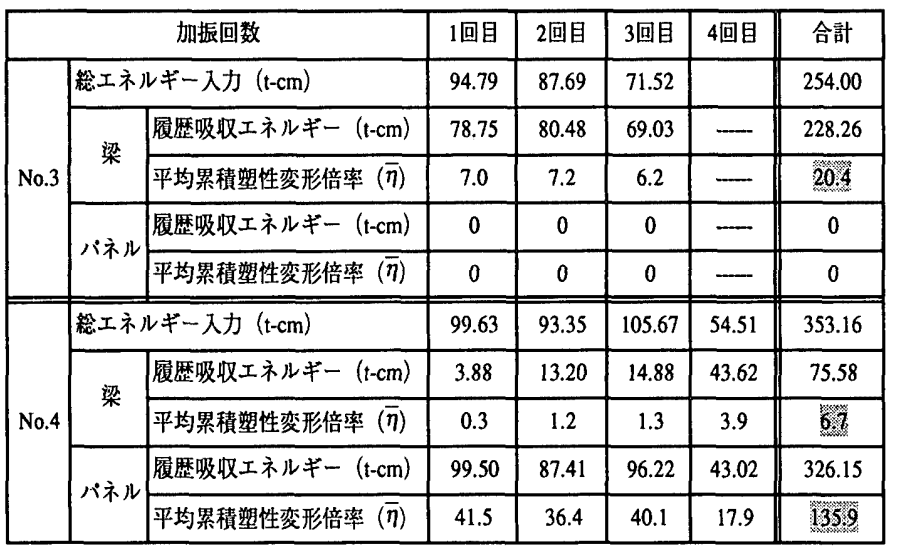

ク合わなくなっている。特に4回目の加振においては、その差が大 きい。一方、No.3では、パネルの履歴吸収エネルギーは0であり、 梁の履歴吸収エネルギーは常に総エネルギー入力より小さくなっ ている。これらのことから、No.4でエネルギーの収支バランスが つり合わないのは、パネルの履歴吸収エネルギーの計算が正確で ないためと考えられる。図7で示したパネルの復元力特性における 横軸のパネルのせん断変形角は、骨組全体の変形角から梁と柱の 変形角分を差し引いて計算したものである。このような変換によ るパネルのせん断変形角の值は、実際のパネルのせん断変形より 大きくなっている可能性が考えられる。

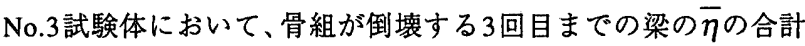
值は20.4であるが、パネル酎力を小さくしたNo.4では、同一断面 の梁が破断するまでの市は、その約 $1 / 3$ の 6.7 となった。No.4の 1

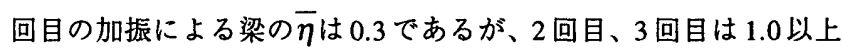

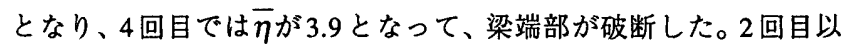
後に梁の $\bar{\eta} か ゙$ 徐々に大きくなっているのは、パネルの塑性化によっ てバネルの降伏耐力が上昇し、2回目以後の試験体の $R_{p}$ の值が 1.0 に近くなっているからと考えられる。なお、No.4の最終的なパネ ルの可は135.9であるが、パネル自体は、まだ耐力低下していない。

図 8 は、No.3、No.4 試験体について、パネル耐力比 $\left(R_{p}\right)$ と梁 及びパネルの履歴吸収エネルギーの関係を示している。横軸がパ ネル耐力比で、縦軸が履歴吸収エネルギーである。がパネルの 履歴吸収エネルギーであり、○からムまでの範囲が、梁の履歴吸 収エネルギー分を表わしている。これらは、表4に示す梁とパネル の履歴吸収エネルギーの合計の值を、それぞれプロットしたもの である。

図中の帯線は、これら試験体のパネルの板厚を変化させた場合、 パネル耐力比 $\left(R_{p}\right)$ に応じて、梁とパネルの履歴吸収エネルギー がどのように変化するか、その傾向を予想したラインである。 $R_{p}$ が 1以上の場合には、ほほ梁のみのエネルギー吸収になると考えられ る。一方、 $R_{p}$ が 1 以下では、パネルでもエネルギーを吸収し、 $R_{p}$ が 小さくなるに伴って、パネルの吸収エネルギーは大きくなると考 えられる。一方、梁が吸収できるエネルギーは、 $R_{p}$ が小さくなると 徐々に低下すると予想される。骨組全体（梁十パネル）の履歴吸 収エネルギーは、R $R_{p}$ を 1 以下にすることにより、パネルのエネル
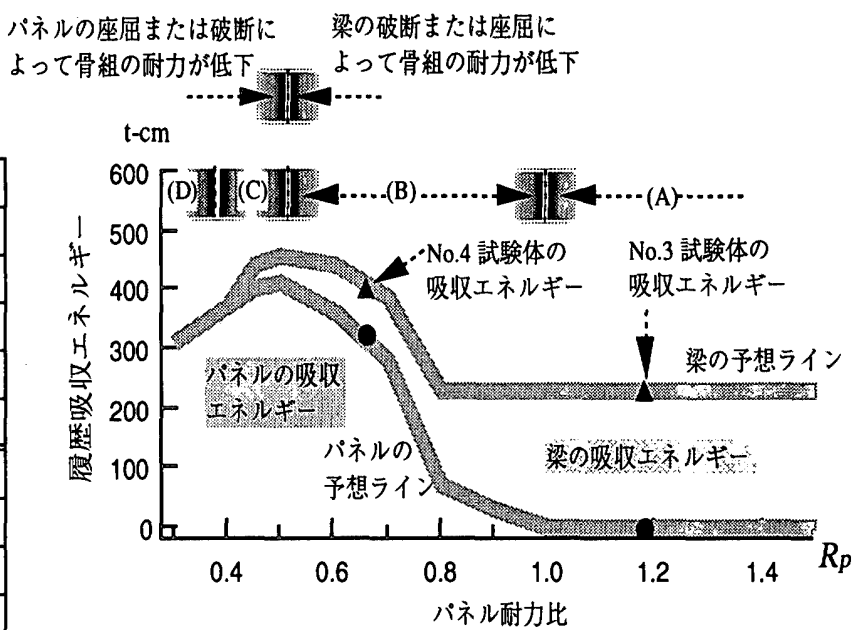

図8 パネル耐力比と部材の履歴吸収エネルギーの関係 
ギー吸収の増加によって、ある耐力比(この図では 0.8 としてる) 以下で、大きくなると予想される。

$R_{p}$ をさらに低下させていくと、骨組の耐力低下が、梁の破断ま たは座屈によって決まる場合から、パネルの座屈または破断に よって決まる場合に変化すると考えられる。この図では、その境 界の $R_{p}$ を 0.5 程度として図を描いている。文献 11）では、 $\mathrm{H}$ 形鋼柱 の場合、この境界の $R_{p}$ は 0.41 であるとしている。この境界となる $R_{p}$ の值は、骨組の条件によって異なると考えられるが、およそ 0.4 $\sim 0.5^{9)}$ 程度と考えられる。

図中には、本論文のはじめで述べた（A）、（B）2つの破壊形態 が生じると考えられる $R_{p}$ の範囲を示している。(C) はパネルの座 屈または破断によって、骨組の耐力が低下すると思われる領域で あり、（D）は梁に塑性変形を生じることなく、パネルだけが塑性 変形し、パネルの座屈または破断によって骨組の耐力が低下する 場合である。（D）の破壊形態があり得るかどうか明らかではない が、角形鋼管パネルが $45^{\circ}$ 方向から載荷された場合には生じる可 能性がある ${ }^{16)}$ 。ただし、本論文の実験だけでは、これらの破壊形 態の境界の $\boldsymbol{R}_{p}$ 值は明確にはできない。

本論文の振動台実験では（A）、（B）の2つの破壊形態となる骨 組の地震応答性状を比較した。パネルで主体的に地震エネルギー を吸収する設計法を一般的なものにするためには、（B）の破壊形 態において、骨組全体（梁十パネル）の履歴吸収エネルギーが大 きくなりはじめる $R_{p}$ の值と、 $R_{p}$ の低下にともない、梁自体の塑性変 形能力がどのように変化 (低下) するか明らかにする必要がある。 また、今後の課題として、上記の (C)、（D）の破壊形態となる骨 組の地震応答性状や、4つの破壊形態の境界となる $R_{p}$ の值も明らか にする必要がある。

\section{4. まとめ}

本論文では、地震時に鉄骨構造骨組の接合部パネルが塑性化す ることによって、骨組全体のエネルギー吸収能力や各部位の弾塑 性応答にどのような影響が生じるか明らかにするために行った振 動台実験について述べた。実験から得られた結論を以下に示す。 1) 梁断面が同一で、パネル板厚だけが異なるNo.1 試験体（R $R_{p}$ は $1.50)$ と No.2 試験体 $\left(R_{p}\right.$ は 0.83$)$ の骨組全体の弾塑性応答を比較 すると、最大耐力はパネル板厚が薄いNo.2 試験体の方がわずかに 小さかった。しかし、变位応答はほとんど変わらなかった。また、 骨組が倒壊するまでの絵エネルギー入力は、ほほ同一であった。 2）同様に、パネル板厚だけが異なるNo.3 試験体（ $R_{p}$ は 1.18）と No.4 試験体（ $R_{p}$ は 0.66）について、骨組全体の弾塑性応答を比較 すると、降伏耐力及び最大耐力はともに、パネル板厚が薄いNo.4 試験体は、No.3 試験体より10\%程度小さかった。しかし、骨組が 耐力低下するまでの最大層間変形角は、No.3試験体が約0.06rad.で あるのに対して、No.4試験体はその約 2 倍の0.12rad.にまで達した 。そのため、骨組が倒壊するまでの総エネルギー入力は、パネル 板厚が薄いNo.4 試験体は、No.3 試験体の約 1.4 倍となった。

3）パネル耐力比が最も小さい No.4 試験体（Rpは 0.66）において も、最終的には梁の破断によって骨組が倒壊した。また、 $R_{p} か ゙ 1.18$ の No.3 試験体と No.4 試験体の梁自体の塑性変形能力を比較する と、同一断面の梁であっても、 $R_{p}$ が 0.66 の No.4 試験体の方が、梁
の耐力と塑性変形能力が低下することがわかった。 4）パネル耐力比 $\left(R_{p}\right)$ を意図的に 1 以下（0.65程度）にして骨組 を設計し、パネルのエネルギー吸収能力を積極的に利用する設計 法は、鉄骨構造骨組の終局時（耐力低下）までのエネルギー吸収 能力を向上させるための一つの方法になる。

\section{謝辞}

本論文の振動台実験は、建設省総合技術開発プロジェクト『次世 代鋼材による構造物安全性向上技術の開発』における研究開発調查 費にて実施したものです。関係各位に感謝の意を表します。この総 プロの「崩壊形と破壊分科会」(主查：井上一朗、京都大学教授) の委員の方々には、振動台実験の結果について、ご意見を賜りまし た。また、日本大学教授秋山宏先生（当時、東京大学教授）には、 振動台実験の結果のまとめ方について、ご指導を賜りました。ここ に記して、深甚なる謝意を表します。

\section{参考文献}

1) 1995 年兵庫県南部地震 鉄骨造建物被害調查報告费,日本建筑学会近畿支部鉄 骨構造部会, 1995年5月

2）長谷川隆：1995年兵庫県南部地震で梁端部が破断した鉄骨造建物の弾塑性 応答性状,日本建築学会構造系論文集 No.498,pp129-136,1997年8月

3）田㴊基嗣,金谷弘,金田興熙：中低層鉄骨造骨組における設計の実状 - 柱,梁 ,接合部パネルの耐力比一,平成5年度日本建築学会近畿支部研究報告集,pp.221224,1993年6月

4）河野昭雄,牧野稳：中低層銅骨組の耐震性に与える柱一はり接合部のせん 断補強の効果についてその 2 バネルゾーンせん断強度が異なる骨組の動的弾 塑性応答性状,日本建築学会論文報告集,第334号,pp18-27,昭和58.12

5）長谷川隆,秋山宏:柱梁接合部の蚛度が地震時の架構の損傷集中特性に与之 る影響,日本建築学会大会学術講演梗概集,pp603-604,1990年10月 6）秋山将光,松尾彰,中村雄治,椋代仁朗,高松隆夫：弱パネル型中低層鋼構造骨 組の地震応答解析,日本建築学会大会学術講演梗概集 C,pp1565-1566,1993年9月 7）長谷川隆,山内泰之:強震時における中低層龬構造骨組の損傷分布に基づく 部材の必要塑性変形能力,日本建築学会構造系論文集 第460号,pp167-175,1994年 6月

8）山成實：柱梁接合部の弾塑性性状が鋼骨組の応答に及はす効果に関する研 究,神戸大学学位論文,1994年1月

9）・田中淳夫, 中尾雅躬：柱梁接合部，カラム No.79,pp22-41,1981 年

10）東清三郎,澤泉紳一，鈴木孝彦：低勒性銅による柱梁接合部の破断性状，一そ の6 十字形静的実験-, 日本建築学会大会学術講演梗概集C-1,pp417-418,1998.9 11）河野昭雄：接合部バネルの力学的構成が銅骨組の耐震性能に与える影響 について ・バネル崩壊型 $\mathrm{H}$ 形龬ラーメン骨組の酎力・変形性状に関する実験 的研究，日本建築学会構造系論文報告集,第435号,pp151-163,1992年5月

12）桑原進,井上一朗：铜管柱・梁接合部バネルのせん断加力実験,日本建築学 会構造系論文集,No.502,pp149-156,1997.12

13）田㴊基嗣,金谷弘：製法の異なる角形鋼管・H形はり接合部の耐力に関す る研究,日本建築学会構造系諭文報告集,第361号,pp104-112;1986年3月 14）銅構造接合部の力学性能と設計法,日本建築学会 構造委貝会 銅構造運営 委員会接合小委員会,pp167-172,pp99-109, 1996.10

15）秋山宏：建築物の耐震極限設計法 第 2 版,東京大学出版会,1987 16）伊藤茂樹,形山忠輝, 岡本晴仁: 鍋構造柱梁接合部バネルの弾塑性挙動,そ の2 部分立体骨みを用いた柱・梁接合部パネルの斜め 45 度方向加力実験,日本 建築学会大会学術講演梗概集C-1,pp473-474,1998.9

(1999年 5 月19日原稿受理, 1999 年 9 月 10 日採用決定） 